\title{
NURSING STUDENTS' KNOWLEDGE AND ATTITUDE ON CONSUMPTION OF IRON SUPPLEMENT TO PREVENT IRON DEFICIENCY ANAEMIA
}

\author{
Mira Trisyani Koeryaman, Ermiati, Yanti Hermayanti, Restuning Widiasih, \\ Tetti Solehati, Anita Setyawati \\ Faculty of Nursing, Universitas Padjadjaran, Bandung, Indonesia \\ Correspondence: mira.trisyani@unpad.ac.id
}

\begin{abstract}
The World Health Organization (WHO) reported that the incidence of anemia in adolescent, especially in developing countries, remained high, including in young women in the West Java provinces. An alternative way to deal with anemia in adolescents is by fulfilling their daily nutrition, especially during menstruation. This study aimed to determine the knowledge and attitudes of nursing students related to the sources of iron supplement in Faculty of Nursing Universitas Padjdjaran. This study applied the descriptive quantitative approach. Samples were chosen using the purposive sampling method, and 197 students from three different years involved in this study. The respondents filled in the Gutman instrument to assess their knowledge and attitude. Results showed that $23.85 \%$ of respondent had a low understanding of iron supplement sources, $41,62 \%$ in the moderate level of understanding, and $34.51 \%$ of respondents had a high level of knowledge. In regard to respondents' attitude, the majority of respondent had a good attitude $(52,79 \%)$ and $(47,20 \%)$ of them had the low attitude. This study informed that there was a group of student who risks of Iron deficiency anemia. It was because of unregular consumption of Iron tablet and their habit related to caffeine consumption that may be affected by iron's absorption in their body. There is a need for a monitoring and implementation program to evaluate adolescents' intake including folic acid, iron supplement, and vitamin to improve hemoglobin levels.
\end{abstract}

Keywords: Anemia, Attitude, Iron Deficiency, Knowledge

\section{INTRODUCTION}

Anemia could occur in all women's life cycle. Various causes of anemia include blood loss due to menstrual period, acute or chronic infection, parasitic infections, and cancer. These causes have a risk of reduced hemoglobin concentration $(\mathrm{Hb})$ levels. The World Health Organization (WHO) estimated that the number of people suffering from anemia worldwide is around two billion, $50 \%$ of anemia is caused by iron deficiency. Lack of other micronutrients, including vitamins $\mathrm{A}$ and B12, folate, riboflavin, and copper would increase the risk of anemia. A study from the WHO found that in developing countries, the prevalence of anemia in the adolescent with no pregnancy (aged 15-49 years) was $41.5 \%$. Indonesia is one of the developing countries with anemia prevalence in young women was $37 \%$ higher than the world's prevalence. According to the 
Household Health Survey (SKRT) in 2012, the anemia prevalence in children under five years old was $40.5 \%$, pregnant women were $50.5 \%$, postpartum mothers were $45.1 \%$, girls aged $10-18$ years were $57.1 \%$ and age $19-45$ years was $39.5 \%$. Young women have the highest risk of anemia, especially in adolescence. In addition, the data from the Ministry of Health, West Java had an incidence of anemia in young women by $51.7 \%$ in 2012

Young women have a high risk of anemia, and this health issue may have short or long-term impacts on their health. The short-term impact includes delayed physical growth and sexual maturity. The long-term impact is related to the pregnancy period such as insufficient nutrition and high risk of maternal or fetal complications. The complication would contribute to maternal mortality, prematurity, low birth weight, and neonatal mortality. One of the causes of anemia is iron deficiency, it means the amount of iron is inadequate to the body's needs. As a result, Iron reserve in the body and the levels of serum ferritin levels are decreased. On the other hand, the reduction in iron reserves is not always associated with the incidence of anemia, however, the condition is a high risk of anemia. This problem can be anticipated if women have a good iron intake in their daily food. One of the mineral sources to form red blood cells is iron (Permenkes, 2014).

Women with a normal menstrual cycle have a risk for anemia. The average of women's blood loss per menstrual period is approximately $30 \mathrm{ml}$ per cycle, and women that experienced menstrual blood loss of $80 \mathrm{ml}$ or more would be related to anemia. Syazwana's (2010) study found that there was a significant relationship between menstruation and decreasing hemoglobin levels in the USU-ACMS medical students. In the society, the majority of women who in menstrual periods did not measure the 
amount of blood loss, very rarely women who aware with their blood loss in the menstrual period, as they consider that menstrual period is the women's monthly event. The preliminary data showed that several girls aged 17-20 years with an average menstrual period of 4-8 days had many symptoms of anemia during menstruation, such as dizziness, fatigue, pale face, difficulty concentrating, weakness, and yawning.

It is important for young women to prevent anemia via primary and secondary prevention actions. One of the primary prevention that has been established by Indonesia government in dealing with anemia in young women, adult women and pregnant women is the iron tablet supplementation program (60 mg FeSO4) and folic acid $(0.400 \mathrm{mg})$ for schools. The secondary prevention includes screening, diagnosis, and treatment of iron deficiency. The Minister of Health Regulation (Permenkes) in 2014 declared that the dose of Iron tablet for women including adolescent is 1 tablet/week and daily Iron table consumption during the menstruation period. Besides tablets, an appropriate intake of folic acid and vitamin $\mathrm{C}$ would increase hemoglobin levels in the blood.

Improving nutritional intake with the balance of nutrition is the most effective way to increase iron levels by consuming foods that contain high iron, for examples vegetables such as spinach, kale, cassava leaves; fruits like red guava, strawberries; nuts like soybeans, red beans, green beans; and food from animal sources including meat, eggs, spleen, and liver (Soebroto, 2009). The preliminary study assessed young women's (17-20 years) daily food found that there was no a significant difference of food that consumed by young women before and during the menstrual period. They ate rice, meat, fish, egg, vegetables, and fruits. At school, young women often consumed imbalance nutrition, such as meatball, "batagor", noodles, and they were rarely consump 
vegies and fruits. Actually, they have knowledge about nutritious food that has benefit to their health, for example, meat, fish, spinach, broccoli, guava, milk, and iron supplement.

The blood loss during the menstrual period in young women approximately 25-30 cc per month. This amount reflected that they lose the Iron's body $12.5-15 \mathrm{mg}$ per month or $0.4-0.5 \mathrm{mg}$ per day for 28 days. When it added to the basal loss, total iron loss of young women was around $1.25 \mathrm{mg}$ per day. According to the frequency of distribution of the blood loss, it can be seen that only $2.5 \%$ of girls needed iron more than $2.4 \mathrm{mg}$ per day. To anticipate the lack of iron intake, every woman should pay attention to iron requirements. Women's nutritional needs are varied per person, it is based on the type of nutrition and age. For example, iron requirements in children 9year-olds are $10 \mathrm{mg}$ and increase to $26 \mathrm{mg}$ in adolescents. Indonesia has a standard rate of Iron for girls aged 16-18 years, which is not much different from FAO and WHO recommendations. According to the government regulation that written by the Minister of Health of the Republic of Indonesia Number 75 of 2013 about recommendation of adequate number of iron, vitamin $\mathrm{C}$, protein, vitamin $\mathrm{A}$, folic acid and zinc for Indonesian young women aged 16-18 were $26 \mathrm{mg}, 75 \mathrm{mg}, 59 \mathrm{mg}, 600 \mathrm{mg}, 400 \mathrm{mg}$, and $14 \mathrm{mg}$, respectively.

It is important to establish the anemia prevention programs because of high incident of iron deficiency anemia in adolescent and adult women. This health problem would impact women's quality of life. Assessing young women's knowledge and their attitudes in applying their knowledge, it is expected that adolescents have the ability to maintain and protect themselves from a high-risk condition that may treat their health. Knowledge is a predisposing factor that would influence health behavior. 


\section{METHODS}

This research was a descriptive explorative research. The population in this study were female students of the Faculty of Nursing at Padjadjaran University, the age range of 17 to 24 years. There were 389 female students participated in this study. They came from three different year entrance: A2012, A 2013, and A 2014. The samples were chosen using the purposive sampling technique. The samples criteria were students of the Nursing Faculty of Padjadjaran University especially active student and not on leave, having a regular menstrual period (monthly), the duration less than four days, and willing to be a respondent.

The samples in this study were 197 students, there were 65-66 respondents for each year entrance. The instruments of this study were a questionnaire to identify student's knowledge using the Guttman scale, and. another instrument to assess their attitudes using a Likert scale. The form of the questionnaire was closed choice questions, the respondents needed to cross their answers and checklist in the available column. The analysis for aspects of knowledge used a dichotomy score (1-0), it means the correct answer had one score (1), and the wrong/double / not filled answer had zero (0). And then, it categorized into a high knowledge level, if the percentage results were $76 \%-100 \%$; moderate level of knowledge if the percentage results were $56 \%-75 \%$; and a lack of knowledge, if the percentage results $<56 \%$.

The attitudes were measured using a Likert scale, the criteria included of Strongly Agree (SS) score: 4, Agree (S) score:3, Disagree (TS) score:2, and Strongly Disagree (STS) score:1. The positive statements had 1 score, and 0 for the negative statement. The normality test for the data distribution was not normal, and then the 
researcher used the median to decide whether respondents' attitude was favorable (> median) or unfavorable (< median). In regard to the daily food consumption, there were two categories which are a good category (> 80\%) and a low category when the percentage $<80$. Whereas the iron consumption was categorized as routine and nonroutine.

\section{RESULTS}

This section describes the study result including the characteristic of respondents, student's knowledge and behavior in preventing Iron Deficiency Anaemia.

Tabel 1 Characteristic of Respondents (N=197)

\begin{tabular}{llcc}
\hline \multicolumn{1}{c}{ Characteristic } & Category & F & \% \\
\hline Age & 17-20 years & 161 & 81,72 \\
& $>20$ years & 36 & 18,27 \\
Menarche & 6-12 years & 77 & 39,08 \\
& $13-20$ years & 120 & 60,19 \\
Menstrual duration & & & \\
& $4-7$ days & 150 & 76,14 \\
Information about & $>7$ days & 47 & 23,85 \\
Anaemia & Yes & 153 & 77,66 \\
& No & 44 & 23,33 \\
\hline
\end{tabular}

Table 1 presents that the majority of respondents had age range $17-20$ years $(81,72 \%)$, ages of menarche were $13-20$ years $60,19 \%)$. The majority of respondents had a menstrual duration from 4 to 7 days $(76,14 \%)$, dan they obtained information of anemia $(77,66 \%)$. 
Tabel 2 Student's Knowledge about Food Sources of Iron (N=197)

\begin{tabular}{rccc}
\hline Variable & Category & F & \% \\
\hline \multirow{3}{*}{ Knowledge } & High & 47 & 23,85 \\
& Moderate & 82 & 41,62 \\
& Low & 68 & 34,51 \\
\hline
\end{tabular}

Table 2 describes $23.85 \%$ of respondents had a good understanding of Iron sources, and almost a half of respondents in the moderate level (41.62\%), and $34,51 \%$ of them had a lack of Iron sources knowledge.

Tabel 3 Student's Attitude in Consuming Foods High in Iron (N 197)

\begin{tabular}{lccc}
\hline Variable & Category & F & \% \\
\hline Attitude & Favorable & 104 & 52,79 \\
& Unfavorable & 93 & 47,20 \\
\hline
\end{tabular}

Table 3 reveal that the majority of respondents had favorable attitude $(52,79 \%)$, while $(47,20 \%)$ of them were unfavorable related to the consumption of foods high in Iron.

Table 4 Food Consumption Patterns and Iron Supplementation (N 197)

\begin{tabular}{lccc}
\hline \multicolumn{1}{c}{ Food sources } & Category & $\mathbf{F}$ & $\boldsymbol{\%}$ \\
\hline Animal protein sources & good & 102 & 51,77 \\
& poor & 95 & 48,22 \\
\hline Plant protein sources & good & 106 & 53,80 \\
& poor & 91 & 46,19 \\
\hline Plant sources & good & 122 & 61,92 \\
& poor & 75 & 38,07 \\
\hline Caffeine consumption & good & 88 & 44,67 \\
& poor & 109 & 55,32 \\
\hline Iron tablet consumption & good & 38 & 19,28 \\
& poor & 169 & 85,78 \\
\hline
\end{tabular}


Table 4 presents that respondents had a good category in consuming food from animal protein sources, plant protein sources, and plant sources $(51,77 \%, 53,80 \%$, and $61,92 \%$, respectively). Respondents had the low pattern related to caffeine $(55,32 \%)$ and Iron tablets consumption $(85,78 \%)$.

\section{DISCUSSION}

This study found that the majority of respondents had a high knowledge related to foods sources Iron. This may influence their behavior in consuming foods high in Iron to prevent Iron deficiency anemia in their daily life or the menstrual period. From the food-based approach, respondents understood that they need to consume Iron tablet during the menstrual period to prevent Iron deficiency anemia. Respondents had a good understanding of foods high in Iron including animal foods sources, vegetables, and fruits. They also knew that the high Iron sources are animal foods sources including meat, fish, liver, and egg. Other food also has high in Iron including spinach, kankung, and cassava leaves. Fruits with high Iron include apple, banana, raisin, nuts, and red bean. Animal protein sources as Iron sources have better absorption (10-20\%) than plant protein sources $(1-2 \%)$.

Consumption of foods high in Iron would help women to meet their Iron need and replace the iron loss in the body. Iron deficiency anemia can be prevented by maintaining a balance between iron intake and iron loss. The amount of iron needed by women varies between one woman and another. It depends on the reproductive history and the amount of blood loss during menstruation. Increasing Iron consumption to meet iron needs is done by increasing the consumption of foods containing heme iron. From a medical-based approach, respondents understood that taking Iron supplement would 
replace Iron loss, besides foods high in Iron. Respondents also knew about the effective way of iron absorption by drinking water or $100 \%$ real fruit juice instead of tea or coffee.

In some people, the administration of iron tablets has side effects such as nausea, stomach pain, vomiting, diarrhea, and constipation. To avoid side effects, it is recommended to drink iron tablets or syrup after dinner. Iron absorption can be maximized when taking iron tablets or syrup using boiled drinking water. Taking Iron tablets would help to reduce signs of anemia. However, there is a possibility that women would suffer other types of anemia.

Mulyawati's research (2003) assessed the effect of administering Iron tablets in reducing the incidence of anemia, it was found that before Iron tablet prescription, the prevalence of anemia was $77.77 \%$ and after being given an Iron tablet or capsule weekly and 1 capsule for 10 days during menstruation, in the period at 16 weeks anemia prevalence decreased to $8.95 \%$. When the body lost the iron, especially during menstruation, the body needs a more nutritional intake that high in iron.

A sufficient health knowledge is an important fundamental to improve understanding in preventing iron deficiency anemia. Knowledge is a basic factor of an individual behavior. Having a high knowledge would encourage women to have an initiative related to health behavior based on their knowledge. Knowledge can be influenced by information sources. This study found that the majority of respondents had received information related to anemia. The information sources include the educational institutions such as schools, campuses; health institutions such as hospitals, health centers, polyclinics; print media such as newspapers, magazines, books; 
electronic media such as television, radio, internet; and direct information from family, friends, and other closest people

In the other word, health promotion sought for individual, group or community behavior to have a positive impact towards health maintenance and improvement. There were various methods of health information, for example, health education, health counseling, health advertisements, banners, billboards, posters, and leaflets. The media is very helpful in delivering health information to the community effectively. Information can be obtained anywhere, anytime, and from anyone. The information would help a person's health behavior. The information provided consist of health promotion knowledge that would influence a personal conducive health behavior. In other words, health promotion had a positive influence on individuals, groups, or communities in maintaining and improving health.

Information or health promotion is aimed to increase people awareness and knowledge about maintaining and improving health for themselves, their families and the community. It can be said, a persuasive approach means influencing individuals, groups, or the community to have a healthy lifestyle. Operationally, this health promotion aims to provide and enhance a person's knowledge and attitudes, it is expected that the person would have good health behaviors in the future. Information provided was about a healthy lifestyle, health promotion, and illness prevention. Furthermore, knowledge enhances people's awareness and would influence their behavior.

Lawrence Green (1980) in Notoatmodjo (2007) analyzed human behavior from the level of health. One of the predisposing factors of health behavior is people knowledge. Adopting Green opinion, it can be said that knowledge is one of the 
predisposing factors that influence the behavior in preventing iron deficiency anemia. Knowledge is the result of knowing, which occurs after a person senses a particular object or stimulus. Sensing occurs through the five senses, knowledge is obtained through the senses of hearing (ears) and the senses of sight (eyes). To produce a knowledge at the time of sensing, attention and perception are very important factors.

Attitude is a personal reaction to a stimulus. Manifestations of attitude cannot be directly seen. Newcomb argued that attitude is a readiness or willingness to act, and is not an act of certain motives. Attitude has not been an act or activity but is a predisposition of an action or behavior (Notoatmodjo, 2010). Attitude begins with the knowledge that is perceived as something is good (positive) or low (negative) then personal's internalization. Knowledge would affect a person's perception when she or he had a negative perception, then the person preferred to void or not do that in their behavior (Azwar, 2008).

The study findings revealed that a half respondent had a favorable attitude in preventing Iron deficiency anemia. The supportive attitude has a big influence including maternity health. The sufficient and high knowledge tends to lead to a supportive attitude. Knowledge sources can be obtained from information received by someone. The existence of new information is a new cognitive foundation for the formation of attitudes towards it. The suggestive messages shared by the information, if the message is a strong enough, it will provide an effective basis for evaluating attitude (Azwar, 2008).

A supportive attitude is not only obtained through knowledge but also willingness and internalization (Azwar, 2008). personal experience (both directly and 
indirectly), culture, other people who are considered important, mass media, institutions or educational institutions were influence a supportive attitude. A personal emotional factor within the individual itself would shape and structure that may be affected by the individual attitude and behavior. One of the bases of the attitude formation was the personal experience.

Nursing students already have experience with health information relating to anemia. They would receive and respond about preventing symptoms of Iron deficiency anemia, positively. Students with a supportive attitude tended to act or behave properly in preventing the occurrence of symptoms of iron deficiency anemia. In contrast, some respondents have a non-supportive attitude in preventing symptoms of iron deficiency anemia. This non-supportive attitude is most likely influenced by the lack of knowledge.

\section{CONCLUSION}

This study found that student who has good and moderate levels of knowledge had a low risk of Iron deficiency anemia. The nursing student would apply their health knowledge in preventing anemia. Existing an attitude begins with a positive perception of knowledge, and then internalizing in their daily life. A positive behavior may be influenced by knowledge. This inline with this study result that the majority of respondent had the favorable attitude. However, there was a student with the low category of knowledge and unfavorable attitude to the anemia prevention program. There is a need of optimization health education program related to the prevention of iron deficiency anemia and it would reduce the risk of iron deficiency anemia. 


\section{REFERENCES}

2010a. Metodologi Penelitian Kesehatan. Jakarta: Rineka Cipta.

2010b. Ilmu Perilaku Kesehatan. Jakarta: Rineka Cipta.

Abidin, S.B.Z. 2010. Hubungan Menstruasi dengan Konsentrasi Hemoglobin pada Mahasiswi FK USU-ACMS Angkatan 2007 dan FK UKM-ACMS Angkatan 2009 Tahun 2010. Available at http://repository.usu.ac.id/bitstream/123456789/21400/4/Chapter\%20II.pdf (diakses tanggal 21 Februari 2011).

Al Rasyid, H. 1994. Teknik Penarikan Sampel dan Penyusunan Skripsi. Bandung: Program Pasca Sarjana Universitas Padjadjaran.

Arikunto, S. 2006. Prosedur Penelitian : Suatu Pendekatan Praktik. Jakarta: PT Asdi Mahasatya.

Azwar, S. 2008. Sikap Manusia : Teori dan Pengukurannya. Yogyakarta: Pustaka Pelajar.

Bobak, Lowdermilk, \& Jensen. 2005. Buku Ajar Keperawatan Maternitas. Diterjemahkan oleh: Maria \& Peter. Jakarta: EGC.

Dahlan, M.S. 2009. Statistik Kedokteran dan Kesehatan edisi 4. Jakarta: Salemba Medika.

Departemen Gizi dan Kesehatan Masyarakat Fakultas Kesehatan Masyarakat Universitas Indonesia. 2008. Gizi dan Kesehatan Masyarakat. Jakarta: PT Raja Grafindo Persada.

Eny K. Kesehatan reproduksi remaja dan wanita. Jakarta: Salemba Medika; 2011. https://desacilelesjtr.wordpress.com/

Fakultas Kedokteran. 2007. Buku Ajar Ilmu Penyakit Dalam. Jakarta: Departemen Ilmu Penyakit Dalam Fakultas Kedokteran Universitas Indonesia.

Farrer, H. 2001. Perawatan Maternitas. Jakarta: EGC.

Irianto, K. 2014. Gizi seimbang dalam kesehatan reproduksi. Bandung: Alfabeta. Patil, SV, et al. 2014. An assessment of interventional strategies for control of anemia among adolescent girls in an urban slum of Karad, Dist. Satara, Maharashtra.

Notoatmodjo, S. 2007. Promosi Kesehatan dan Ilmu Perilaku. Jakarta: Rineka Cipta.

Official Journal of the American Academy of Pediatrics. 2006. Menstruation in girls and adolescents: using the menstrual cycle as a vital. Available at : http://pediatrics.aappublications.org/cgi/reprint/118/5/2245 (diakses tanggal 21 Februari 2011). 
Permenkes. Peraturan Menteri Kesehatan Republik Indonesia Nomor 88 Tahun 2014 tentang standar tablet tambah darah bagi wanita usia subur dan ibu hamil. Indonesia.

Potter, P.A., \& Perry, A.G. 2005. Buku Ajar Fundamental Keperawatan : Konsep, Proses, dan Praktik. Diterjemahkan oleh: Yasmin. Jakarta: EGC.

Primary Health Care, Jatinangor, Indonesia: Iron Deficiency Anemia or $\beta$-Thalassemia Trait. Journal Anemia, Hindawi. Volume: 2017.

Purwanto, H. 1994. Pengantar Statistik Keperawatan. Jakarta: EGC.

Rezaie-pour et al. 1999. Study of The Practice of Female Medical Students in The Prevention of Iron Deficiency Anemia due to Menstruation. Available at : http://web.ebscohost.com/ehost/detail?hid=113\&sid=4f4f38e2-4083-4aa6-818ed33757d07a3f\%40sessionmgr114\&vid=1\&bdata=JnNpdGU9ZWhvc3QtbGl2ZQ $\% 3 \mathrm{~d} \% 3 \mathrm{~d} \# \mathrm{db}=\mathrm{c} 8 \mathrm{~h} \& \mathrm{AN}=2004182916$ (diakses tanggal 22 Februari 2011).

Riduwan. 2002. Skala Pengukuran Variabel-Variabel Penelitian. Bandung: Alfabeta.

Satuan Tugas Remaja IDAI. 2010. Bunga rampai kesehatan remaja. Bandung: Badan Penerbit Ikatan Dokter Anak Indonesia.

Sirajudin, Mustamin, Nadimin, Rauf, S. 2015. Survei konsumsi pangan. Jakarta: EGC. Susanti, AI, et al. 2017. Low Hemoglobin among Pregnant Women in Midwives Practice

Soebroto, I. 2009. Cara Mudah Mengatasi Problem Anemia. Yogyakarta: Bangkit.

Sugiyono. 2010. Metode Penelitian Kuantitatif Kualitatif dan R\&D. Bandung: Alfabeta.

Sunaryo. 2004. Psikologi Untuk Keperawatan. Jakarta: EGC.

Tarwoto, N. 2007. Buku Saku Anemia Pada Ibu Hamil, Konsep dan Penatalaksanaan. Jakarta: Trans Info Media.

Tayel, DI. 2015. Anemia and Its Associated Factors among Adolescents in Alexandria, Egypt. WHO. 2008. Worldwide prevalence of anaemia 1993-2005. Spain: WHO Library Cataloguing.

Waryono. 2010. Gizi Reproduksi. Yogyakarta: Pustaka Rihama.

WHO. 2011. Prevention Of Deficiency Anaemia In Adolescents Role Of Weekly Iron And Folic Acid Supplementation Iron. India: WHO. 